Frrat Üniversitesi Sosyal Bilimler Dergisi

The Journal of International Social Sciences

Cilt: 27, Say1: 1, Sayfa: 53-61, ELAZIĞ-2017

\title{
SİBERAYLAKLIK NEDENLERİ ÖLÇEĞİ: BİR ÖLÇEK GELIŞTIRME ÇALIŞMASI
}

\author{
Reasons Of CyberloafingScale: A Scale Development Study
}

Zülfü GENÇ ${ }^{1}$

Süleyman Burak TOZKOPARAN ${ }^{2}$

\section{ÖZET}

$\mathrm{Bu}$ çalışmayla, öğrencilerin bilgisayar laboratuvarında işlenen derslerde siber aylaklık davranışına yönelme nedenlerini belirleyebilmek amacıyla bir ölçek geliştirilmiştir. Ölçek maddeleri oluşturulur iken alanyazında bulunan siber aylaklık konusu ile ilgili yapılan çalışmalar incelenmiş, bunun yanında uzman görüşüne başvurulmuştur. Çalışma kapsamında gerçekleştirilen uygulamalar 2014-2015 Akademik y1lında Fırat Üniversitesi Eğitim Fakültesi ve Mühendislik Fakültesinde öğrenim görmekte olan öğrenciler üzerinde gerçekleştirilmiştir. Çalışmanın 1. uygulamasına 92 kadın 70 erkek toplam 162 öğrenci katılmıştır. 2. uygulamaya ise 254 'ü erkek, 223'ü kadın toplam 477 öğrenci katılmıştır. 3. aşamada test-tekrar test yöntemi kullanılmış, ölçek iki hafta arayla 24 erkek ve 20 kadın olmak üzere toplam 44 öğrenciye uygulanmıştır. Toplanan veriler SPSS ve AMOS programları ile analiz edilmiştir. Ölçeğin geçerliğini araştırma için KMO ve Bartlett testi, açımlayıcı ve doğrulayıcı faktör analizi yapılmış, madde ayırt edicilikleri hesaplanmıştır. Ölçeğin güvenirliğini araştırmak için ise ölçeğin iç tutarlılık katsayısı hesaplanmıştır. Toplanan veriler ile yapılan analizlere göre, Cronbach's Alfa güvenirlik katsayısı ölçek için 0.83( $>0.70)$ olarak bulunmuştur. Ölçeğin kararlılığını belirlemek için test-tekrar test yöntemi kullanılmış, ölçek iki hafta arayla 20 erkek, 24 kadın toplam 44 öğrenciye uygulanmıştır. Ölçeğe ilişkin Pearson korelasyon testi sonuçları ve Cronbach's Alfa güvenirlik katsayıları ölçeğin güvenirlik düzeyinin yeterli olduğunu göstermektedir. Ayrıca, yapılan testler ölçeğin "Güdülenme", "Yürütücü Kaynaklı Nedenler" ve "Derse İlişkin Tutum" olmak üzere toplam 3 faktörde toplandığını göstermiştir. Sonuç olarak; Siberaylaklık Nedenleri Ölçeği üç faktör altında toplanan, 11 maddeden oluşmuş 5'li Likert tipi bir ölçektir. Analizler ölçeğin, bireylerin siber aylaklık davranışlarının nedenlerini ölçmeye dönük geçerli ve güvenilir bir araç olduğunu ortaya koymuştur. Çalışma sonunda elde edilen bu sonuçlara göre, Siberaylaklık Nedenleri Ölçeği’nin öğrencilerin bilgisayar laboratuarlarında gerçekleştirdikleri siberaylaklık davranışlarını ve nedenlerini belirlemede, eğitim kurumlarında bir ölçme aracı olarak kullanılabileceği söylenebilir.

Anahtar Kelimeler: siberaylaklık, siberaylaklık nedenleri, ölçek geliştirme, geçerlik, güvenirlik

\section{ABSTRACT}

With this study, It is aimed to determine the reasons for cyberloafing behaviors of thestudents in computerlabs. Reasons of Cyberloafing Scale has been developed to determine cyberloafing behaviors of undergraduate students. In the forming period of the scale items, previous studies on the cyberloafing subject in the literature have been examined and additionally it has been consulted experts for their opinions. The study has been conducted in the academic year of 2014-2015 and the participants of the study have been composed of the students studying in the Faculty of Education and Faculty of Engineering in Firat University. 92 female and 70 male, 162 students in total have been participated in the first implementation. 254 maleand 223 female, a total of 477 students have been participated in the second implementation.. In the third implementation, test-retest method was used and the scale was applied to a total of 44 students, including 24 men and 20 women at two week intervals. The data collected at the end of the implementations have been analyzed with IBM SPSS and AMOS. In order to detect the validity of the scale, KMO and Bartlett's test and exploratory and confirmatory factor analyzes have been performed, item discriminations have been designated. For the purpose of assessing the reliability of the scale, the internal consistency coefficient has been calculated. Test-retest method has been used to determine the reliability of the scale. According to the analysis performed with data, the scale's Cronbach's alpha reliability coefficient is

\footnotetext{
${ }^{1}$ Yrd. Doç. Dr.,Fırat Üniversitesi, Eğitim Fakültesi, Bilgisayar ve Öğretim Teknolojileri Eğitimi Bölümü, ELAZIĞ, email: zulfugenc@gmail.com

${ }^{2}$ Doktora öğrencisi, Eskişehir Anadolu Üniversitesi, Eğitim Bilimleri Enstitüsü, Bilgisayar ve Öğretim Teknolojileri Eğitimi Bölümü, ESKIŞEHIR, email: buraktozkoparan@gmail.com
} 


\section{F.Ü. Sosyal Bilimler Dergisi 2017-27/1}

$0.83(>0.70)$ and Pearson correlation coefficents are sufficient. In addition, the tests have been showed that the level of reliability of the scale sufficient and the scale items gather under three factors named "motivation", "attitude towards lesson" and "instructor-induced reasons". Consequently; Reasons of Cyberloafing Scale is a scale consisting of 5 points Likert type with 11 items which grouped under three factors. The analysis phase has been revealed that The Cyberloafing Scale is a valid and reliable tool for measuring the behavior of cyberloafing. According to the results obtained from this study, it can be said that Reasons of Cyberloafing Scale can be used as a measuring intrument in educational institutions for measuring reasons of students' cyberloafing behaviors in computerlabs.

Keywords: cyberloafing, reasons of cyberloafing, scaledevelopment, reliability, validity

\section{GİRIŞ}

Bilgisayar laboratuvarlarında yapılan derslerde, öğrencilerin bilgisayarı ve interneti ders dış1 farklı amaçlarla kullanması büyük bir problem olarak göze çarpmaktadır. Alanyazın incelendiğinde, bu durumun birçok araştırmaya konu olduğu ve siberaylaklık olarak tanımlandığ 1 görülmektedir (Çınar \& Karcıoğlu, 2015; Özkalp, Aydın \& Tekeli, 2012: Yaşar \& Yurdugül, 2013). Siberaylaklık ise; ders saati içinde, internetin ders dışı etkinlikler için kullanılması davranış1 olarak tanımlanabilir (Kalaycı, 2010; Yaşar, 2013). Başka bir deyişle siberaylaklık, öğrencilerin bilgisayar laboratuvarında işlenen derslerde kendilerine verilen görevleri yapmak ya da anlatılanları dinlemek yerine, bilgisayar ve interneti kullanarak dersle alakası olmayan etkinlikler yapmaları olarak tarif edilebilir.

Alanyazında sözkonusu davranışların farklı araştırmacılar tarafindan farklı terimlerle ifade edildiği görülmektedir (Örücü \& Yıldız, 2014; Pychyl, 2001; Ugrin, Pearson \& Odom, 2011; Ünal \& Tekdemir, 2015). Bu terimlerden siberaylakl1k "cyberloafing" terimi ise Lim (2002) tarafindan kullanılmış ve sonrasında araştırmacılar tarafından yaygın olarak kullanılmaya başlanmıştır (Jia, 2008; Kurt, 2011; Lim, 2005;). Siberaylaklık davranışları ile ilgili olarak yapılan araştırmalarda başlangıçta ofis ve çalışma ortamlarında gerçekleştirilen siberaylaklık davranışları üzerine odaklanılmıştır (Henle, Kohut \& Booth, 2009; Lim \& Teo, 2006; Sevier, 2008). Daha sonraları ise eğitim-öğretim ortamlarında, bilgisayar laboratuvarlarında ders yürütücüleri tarafından gözlenen bu davranışlar birçok araştırmaya konu olmuştur (Baturay \& Toker, 2015; Kalaycı 2010; Yaşar, 2013; Yılmaz, Y1lmaz, Öztürk, Sezer \& Karademir, 2015). Ancak bu tür ortamlarda öğrencilerin gerçekleştirdiği siberaylaklık davranışları hakkında alanyazında geniş bir anlayış oluştuğunu söylemek mümkün değildir.

Siberaylaklık davranışı, öğretmenler, akademisyenler ve bilgisayar laboratuvarında ders veren tüm eğitimciler için dersi yürütmeyi zorlaştıran etkenlerden biridir. Öğrencilerin siber aylaklık davranışlarını konu alan çalışmalar incelendiğinde elde edilen bulgulara göre, siberaylaklık davranışı genel olarak öğrenci motivasyonunun eksikliği, ortamın sıkıcılığı, dersin konusunun veya öğretmenin sevilmemesi ve bilgisayar laboratuvarında uzun süre zaman geçirilmesi ve kişilik özellikleri gibi nedenlere bağlanmaktadır (Baturay \& Toker, 2015; Kalayc1, 2010; Kurt, 2011; Yaşar, 2013). Ayrıca siberaylaklık davranışlarını ve bu davranışların düzeylerini belirleme hususunda, alanyazında bulunan ölçme araçlarının artırılması gerektiği söylenebilir.

Ergün ve Altun (2012) yaptıkları çalışmada eğitim öğretim ortamlarında öğrencilerin sergilediği siberaylaklık davranışları hakkındaki görüşlerini araştırmışlardır. $\mathrm{Bu}$ araştırmada siberaylaklık davranışının nedenleri "motivasyon", "ortam", "öğretmen”, "zaman” ve "derse hedeflenme" olmak üzere 5 başlık altında toplanmıştır. Ergün ve Altun (2012)'un çalışmasının sonuçlarına göre; tüm öğrenciler ya kendileri siberaylaklık davranışlarını gerçekleştirmekte ya da arkadaşlarının siberaylaklık davranışlarında bulunduklarını gözlemlemektedirler ve öğrenciler bu davranışlar konusunda çevrelerinde bulunan diğer öğrencilerden etkilenmektedirler.

Alanyazındaki araştırmaların sonuçları dikkate alındığında (Ergün \& Altun, 2012; Kalaycı, 2010; Keser, Kavuk \& Numanoğlu, 2016; Yaşar, 2013); öğrencilerin bilgisayar laboratuvarında işlenen derslerde yapmış oldukları siberaylaklık davranışlarının ölçülmesi ve nedenlerinin incelenmesi gereken bir konu olduğu ortaya çıkmaktadır. Bu nedenle bu araştırmada siberaylaklık 
davranışlarının nedenlerini ölçme konusunda bir ölçme aracı geliştirilmesi ve alanyazına kazandırılması amaçlanmaktadır.

\section{YÖNTEM}

$\mathrm{Bu}$ araştırmada yöntem olarak betimsel tarama modeli kullanılmaktadır. Betimsel tarama modelinde varlığı bilinen bir olay veya durum nitel ya da nicel yolla betimlenmeye çalışılır (Çepni, 2010; Karasar, 2008). Siberaylaklık Nedenleri Ölçeği'nin geliştirilmesi sırasında, ölçek maddelerini hazırlama, kapsam geçerliliği, deneme çalışması, yapı geçerliliğini ve güvenirliliğini belirleme çalışmaları gerçekleştirilmiştir. Çalışmada toplanan veriler üzerinde istatistiksel işlemlerin yapılması amacıyla (ölçeğin geçerlik ve güvenirlik analizlerini yapmak üzere) SPSS ve AMOS programları kullanılmıştır.

\section{Örneklem}

Bu çalışmada örnekleme yöntemi olarak amaçlı örnekleme yöntemlerinden kolay ulaşılabilir durum örneklemesi kullanılmıştır. Bu örneklemede belirli bir evrenden erişilmesi kolay ve pratik olan kişilere ulaşılır (Yıldırım \& Şimşek, 2008).

Geliştirilen maddeler Google Formlar aracıllğıyla çevrimiçi ortama aktarılmış ve öğrencilerle yine çevrimiçi ortamda paylaşılmışıır. Çalı̧̧manın birinci ve ikinci aşamasındaki örneklem gönderilen formu gönüllülük esasına göre dolduran öğrencilerden oluşmuş̧tur. Buna göre çalışmanın 1. aşamasının örneklemi 92 kadın, 70 erkek olmak üzere toplam 162 öğretmen adayından oluşmaktadır. 2. aşamanın örneklemi 223 kadın, 254 erkek, toplam 477 öğrenciden oluşmaktadır. 3. aşamada ise test-tekrar test yöntemi kullanılmış, ölçeğin iki hafta arayla uygulandığı örneklem 24 erkek ve 20 kadın olmak üzere Bilgisayar ve Ögretim Teknolojileri Eğitimi Bölümü 2. sinıfta öğrenim gören toplam 44 öğrenciden oluşturulmuştur. Araştırmaya katılan öğrencilerin daha önce bilgisayar laboratuvarında ders alma deneyimi olmasına dikkat edilmiştir.

\section{Madde Havuzu}

Ölçek maddelerinin oluşturulmasında öncelikli olarak alanyazın taraması yapılmış ve bulunan çalışmalar incelenmiş̧ir. Bu çalışmaların sonuçlarına göre, siberaylaklık davranışlarının genel nedenleri belirlenmeye çalışılmıştır. Belirlenen nedenlerin her biri bir önerme olacak şekilde maddeleştirilmiş, madde havuzuna eklenmiştir. Bu şekilde oluşturulan toplam 16 önerme ile madde havuzu tamamlanmıştır. Bu maddeler olumsuz önermelerden oluşmaktadır. Ayrıca ölçek 5'li likert tipinde düzenlenmiş olup, bu seçenekler; "(1) Hiçbir zaman”, “(2) Nadiren”, (3) Ara sıra”, "(4) Genellikle" ve "(5) Her zaman” şeklinde belirlenmiş ve puanlanmıştır.

\section{Uzman Görüşü (Kapsam Geçerliği)}

Araştırmacılar tarafindan oluşturulan madde havuzunun örtüşen maddeler ve kapsam geçerliği açısından incelenmesinde iki bilgisayar ve öğretim teknolojileri eğitimi alanı uzmanından yardım ve görüş alınmıştır. $\mathrm{Bu}$ inceleme sonucunda uzmanlar tarafindan iki maddenin önermelerinin madde havuzunda bulunan başka iki madde tarafından anlam ve içerik bakımından kapsandığına dair gelen öneri doğrultusunda iki madde çalışmadan çıkarılmıştır. Ek olarak madde havuzunda bulunan maddeler Türkçe eğitimi alan uzmanı tarafindan incelenmiş, ifadesinin anlaşılmasında güçlük olduğu şeklinde dönüt alınan üç madde, öneriler doğrultusunda daha sade ve daha anlaş1lır hale getirilmiştir.

\section{Deneme Çalışması}

Alanyazındaki çalışmaların kapsamlı şekilde incelenmesi ve uzman görüşünün alınması ile oluşturulan taslak ölçek bilgisayar laboratuvarında ders alma deneyimi fazla olan Fırat Üniversitesi Eğitim Fakültesi Bilgisayar ve Öğretim Teknolojileri Eğitim bölümünde dördüncü sinıfta öğrenim görmekte olan 30 öğrenciye uygulanmıştır. Öğrencilerden, anlamakta zorlandıkları maddeleri belirlemeleri ve yorumlamaları istenmiştir. $\mathrm{Bu}$ uygulama sonucunda ve uzman görüşleri 


\section{F.Ü. Sosyal Bilimler Dergisi 2017-27/1}

doğrultusunda maddeler yeniden düzenlenmiş, toplam 14 madde geçerlik ve güvenirlik çalışmas1 için hazır hale getirilmiştir.

\section{Faktör Analizi}

Bu çalışmada taslak ölçeği geliştirme amacıyla açımlayıcı faktör analizi, ölçeği test etmek amacıyla ise doğrulayıcı faktör analizi gerçekleştirilmiştir. Bir veri seti üzerinde faktör analizi yapılabilmesi için Keiser-Meyer-Olkin (KMO) değerinin .60 ve üzerinde olması ve Bartlett testinin de anlamlı olması $(\mathrm{p}<=.05)$ gerekmektedir (Büyüköztürk, 2007).

Açımlayıcı faktör analizinde anlamlı bir kavramsal yapıya ulaşma adına; taslak ölçekteki yetersiz maddeler tespit edilir, ölçtüğü faktörler konusunda bilgi edinilir (Büyüköztürk, 2007). Doğrulayıcı faktör analizinde ise ölçeğin kuramsal faktör yapısı ile örneklemden elde edilen verilerin uyum sağlayıp sağlamadığı (uyum iyiliği) ve puanların faktöriyel değişmezliği test edilir (Tuncer \& Y1lmaz, 2013). Ölçekten elde edilen verilerin modele uyumu konusunda X2/sd, AGFI, GFI, CFI, RMSEA ve SRMR değerleri incelenir ve bu değerlerin alanyazındaki uyum indeks sinırlarıyla büyük ölçüde bağdaşması gerekir (Tuncer \& Yılmaz, 2013).

$\mathrm{Bu}$ çalışmada, oluşturulan taslak ölçeğin 1. uygulamada 162 öğrenciye uygulanmas1 sonucunda elde edilen veriler üzerinde açımlayıcı faktör analizi yapılmıştır. Ölçeğin faktörlere ayrılma durumu temel bileşenler analizi ile belirlenmiştir. Temel bileşenler analizinde değişkenlerin bileşene hangi ölçüde etki ettiği incelenir (Field, 2013). Analiz sonuçlarına göre yap1 geçerliğini sağlayan maddeler ölçeğin son haline dahil edilmiştir. 2. Aşamada 477 öğrenciye uygulanan ölçekten toplanan veri üzerinde doğrulayıcı faktör analizi gerçekleştirilmiştir.

\section{Güvenirlik Hesaplama Aşaması}

Ölçeğin güvenirliği konusunda Cronbach's Alpha güvenirlik katsayıları belirlenmiş, ölçeğin kararlılık düzeyine ilişkin test-tekrar test yöntemi kullanılarak ölçeğin Pearson korelasyon katsayısı hesaplanmıştır. Açımlayıcı ve doğrulayıcı faktör analizi ile elde edilen ölçek formu, Fırat Üniversitesi Eğitim Fakültesi Bilgisayar ve Öğretim Teknolojileri Eğitim bölümünde ikinci sınıfta öğrenim görmekte olan toplam 44 öğrenciden oluşan yeni bir gruba uygulanmış, iki hafta aradan sonra ise aynı gruba ölçek yeniden uygulanmıştır. Çözümleme aşamasında ölçek maddelerinin Cronbach's Alpha katsayısı ile parça-bütün korelasyonuna (Item Total Correlation) bakılmıştır.

\section{BULGULAR VE YORUM}

\section{Ölçeğin Geçerliğine İlişkin Bulgular}

Açımlayıcı Faktör Analizi

Çalışmanın 1. aşamasında uygulanan taslak ölçeğin yapı geçerliğini test etmek amacıyla SPSS programı ile $\mathrm{KMO}$ ve Bartlett testleri yapılmış, $\mathrm{KMO}=.83$; Bartlett testi sonucu ise $\chi 2=581,899$; $\mathrm{sd}=55(\mathrm{p}=.00)$ olarak bulunmuştur. Bu değerlerden hareketle toplanan verinin faktör analizi için uygun olduğu sonucuna varılmıştır.

14 maddeden oluşan taslak ölçeğe ilişkin varimax döndürme yöntemi kullanılarak yapılan açımlayıcı faktör analizi sonucunda 1,4 ve 6 . maddelerin faktör yüklerinin .30'un altında olduğu görülmüş ve ölçekten çıkarılmıştır. Taslak ölçeğin diğer maddelerinin madde faktör yüklerinin ise .40 ile .82 arasında değiştiği ve 3 faktöre ayrıldığ 1 görülmüştür. Faktörlere ayrılan maddeler incelenmiş ve bu faktörler "Derse İlişkin Tutum", "Güdülenme" ve "Yürütücü Kaynaklı Nedenler" şeklinde açıklanmıştır. Taslak ölçeği oluşturan maddelerin faktör yüklerine ilişkin bilgiler Tablo 1 'de verilmiştir. 
Tablo 1. Siber aylaklık Nedenleri Ölçeği’ni Oluşturan Maddelerin Faktör Yükleri

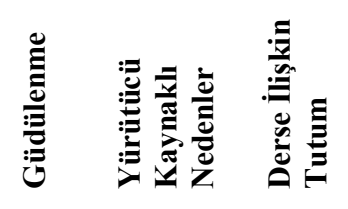

\begin{tabular}{lr}
\hline 2. Ders esnasında motivasyon sorunu yaşıyorum. & .82 \\
\hline 3. Ders & 80
\end{tabular}

$\begin{array}{ll}\text { 3. Ders s1k1c1 geliyor. } & .80 \\ \text { 5. Laboratuvar ortamı sikıcı geliyor. } & .63\end{array}$

9. Derse konsantre olamiyorum.

\begin{tabular}{ll}
\hline 7. Ders hocasinı sevmiyorum. & .50 \\
\hline 8. Derste tek yöndu & .795
\end{tabular}

8. Derste tek yönlü iletişimin olması (sadece hoca konuşuyor) bana göre değil. $\quad .55$

\begin{tabular}{ll}
\hline 13. Bildiğim bir konuyu tekrar dinlemek istemiyorum. & .78 \\
\hline
\end{tabular}

\begin{tabular}{ll}
\hline 14. Derslerde verilen görevler için yeterli süre verilmiyor. & .69
\end{tabular}

\begin{tabular}{lr} 
10. Dersi sevmiyorum. & .40 \\
\hline 11. Derste basali & .73
\end{tabular}

\begin{tabular}{ll} 
11. Derste başarılı olamayacağımı düşünüyorum. & .43 \\
\hline
\end{tabular}

12. Dersin bana yararı olmayacağını düşünüyorum.

Tablo 1'de görüldüğü üzere "Güdülenme" faktöründe 4, "Yürütücü Kaynaklı Nedenler" faktöründe 4 ve "Derse İlişkin Tutum" faktöründe 3 madde bulunmaktadır.

Faktör yüklerinin düşük olmasından dolayı 3 maddenin ölçekten çıkarılması ve faktörlerinin belirlenmesinin ardından ölçekte bulunan 11 maddenin konuyu hangi oranda açıkladığıyla ilgili olarak faktörlerin ve ölçeğin bütününün toplam varyansı hangi oranda açıladığı (total variance explained) incelenmiştir. Faktörlerin ve ölçeğin bütününün toplam varyansı açıklama oranları Tablo 2'de verilmiştir.

Tablo 2. Siberaylaklık Nedenleri Ölçeğinin Toplam Varyansı Açıklama Oranları

\begin{tabular}{lc}
\hline Faktör & Toplam AçılananVaryans (\%) \\
\hline Güdülenme & 38.1 \\
\hline Yürütücü Kaynaklı Nedenler & 13 \\
\hline Derse İlişkin Tutum & 9.7 \\
\hline \multicolumn{1}{c}{ Toplam: } & 60.8 \\
\hline
\end{tabular}

Tablo 2'de görüldüğü üzere ölçeğin "Güdülenme" faktörünün toplam varyansın \%38.1'ini, "Güdülenme" ve "Yürütücü Kaynaklı Nedenler" faktörlerinin birlikte toplam varyansın \%51.1'ini, üç faktörün birlikte toplam varyansın \%60.8'iniaçıkladığı görülmektedir. Sosyal bilimler alanında bu değerin \%50'nin üzerinde olmasının beklendiği düşünüldügünde, ölçek maddelerinin açıkladığı varyansın yeterli düzeyde olduğu söylenebilir (Kara, 2010).

\section{Doğrulayıcı Faktör Analizi}

Çalışmanın 2. aşamasında elde edilen verilerin yapı geçerliğini test etmek amaciyla SPSS programı ile $\mathrm{KMO}$ ve Bartlett testleri yapılmış, $\mathrm{KMO}=.85$; Bartlett testi sonucu ise $\chi 2=1399,844$; $\mathrm{sd}=55(\mathrm{p}=.00)$ olarak bulunmuştur. Bu değerlerden hareketle toplanan verinin faktör analizi için uygun olduğu sonucuna varılmıştır. Açımlayıcı faktör analizi sonucunda 3 faktörden oluştuğu belirlenen ölçeğin faktör yapılarını doğrulamaya yönelik olarak çalışmanın 2. aşamasında maksimum olasılık tekniği kullanılarak doğrulayıcı faktör analizi yapılmıştır.

Doğrulayıcı faktör analizine ilişkin ulaşılan standartlaştırılmış uyum indeksleri Tablo 3'te verilmiştir.

Tablo 3. Ölçeğin faktör yapısının Uyum İndeksleri

\begin{tabular}{cc}
\hline Uyum İndeksi & Uyum Değeri \\
\hline CMIN/DF & 3.70 \\
\hline GFI & .948 \\
\hline CFI & .919 \\
\hline AGFI & .916 \\
\hline NFI & .893 \\
\hline RMSEA & .075 \\
\hline SRMR & .0472 \\
\hline
\end{tabular}




\section{F.Ü. Sosyal Bilimler Dergisi 2017-27/1}

Maksimum olasılık tekniği kullanılarak yapılan doğrulayıcı faktör analizi sonucunda uyum indeksleri $\mathrm{CMIN} / \mathrm{DF}\left(\mathrm{X}^{2} / \mathrm{sd}\right)=3,70 ; \mathrm{GFI}=.948 ; \mathrm{CFI}=.919 ; \mathrm{AGFI}=.916 ; \mathrm{NFI}=.893$; RMSEA $=.075$ ve $\mathrm{SRMR}=.0472$ olarak bulunmuştur. $\mathrm{Bu}$ bilgiler 1şığında ölçeğin uyum indekslerinin iyilik değerlerinin hepsinin iyi uyum ve kabul edilebilir uyum aralıkları arasında olduğu söylenebilir (Bayram, 2010; Meydan \& Şeşen, 2011). Dolayısıyla elde edilen verilerle ölçeğin faktör yapısının doğrulandığı yorumunda bulunulabilir. Doğrulayıcı faktör analizine ilişkin ulaşılan bulgular Şekil 1 'de gösterilmiştir.

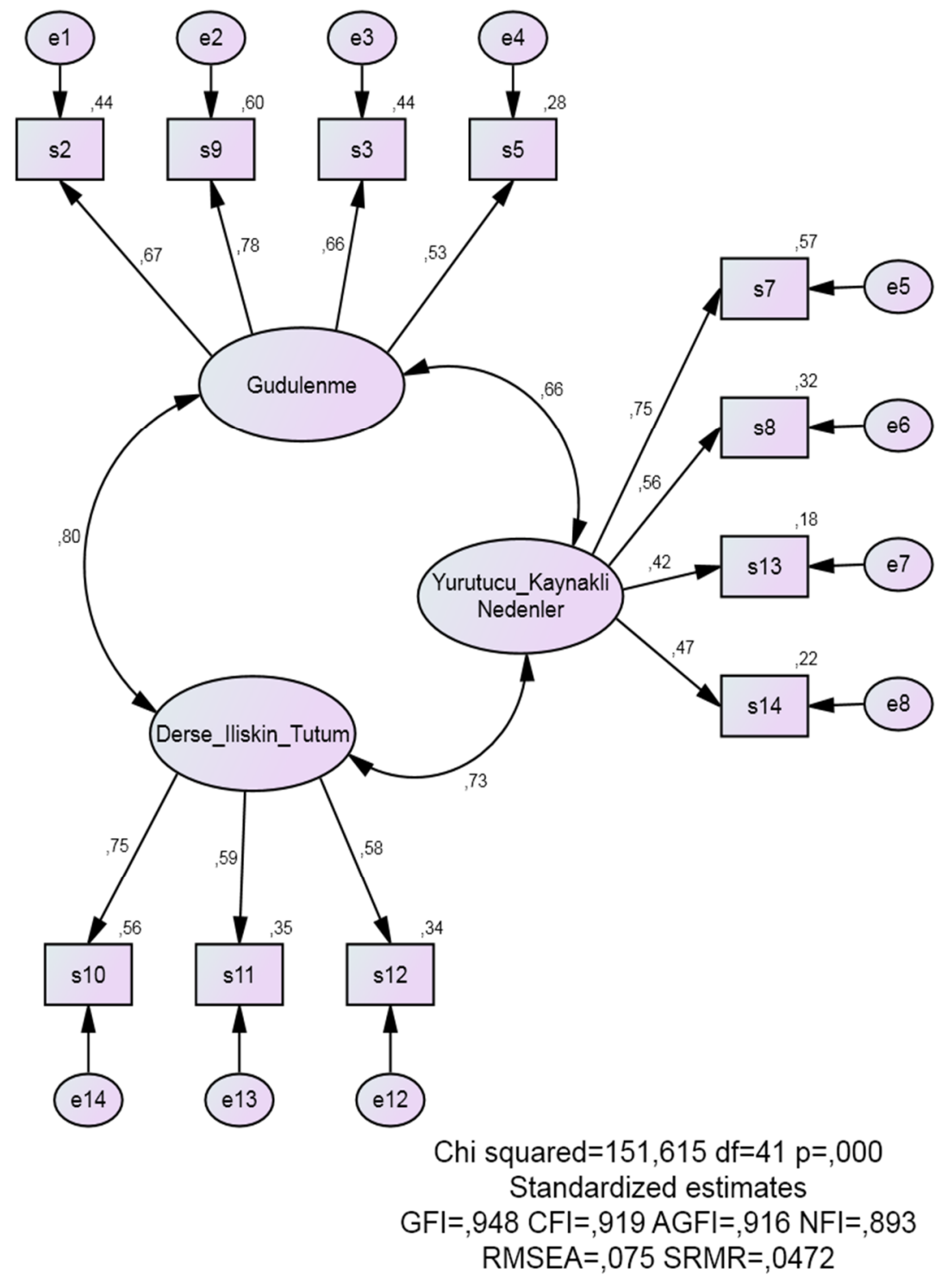

Şekil 1. Siberaylaklık Nedenleri Ölçeğinin Faktör yapısına ilişkin Doğrulayıcı Faktör Analizi Sonuçları

Siberaylaklık Nedenleri Ölçeği için yapılan doğrulayıcı faktör analizi sonucunda; faktör yüklerinin .42 ile .78 arasında değiştiği Şekil 1'de görülmektedir. Maddelerin faktör yükleri "Güdülenme" faktöründe 2. madde için .67, 3. madde için .66, 5. madde için .53, 9. madde için .78 'dir. "Yürütücü Kaynaklı Nedenler" faktöründe 7. madde için .75, 8. madde için .56, 13. madde için .42, 14. madde için .47'dir. "Derse İlişkin Tutum" faktöründe 10 . madde için $.75,11$. madde için .59, 12. madde için .58'dir. "Güdülenme" faktörü ve "Yürütücü Kaynaklı Nedenler" faktörü arasındaki korelasyon katsayısının .66, "Yürütücü Kaynaklı Nedenler" faktörü ve "Derse İlişkin 
Siber Aylaklık Nedenleri Ölçeği: Bir Ölçek Geliştirme Çalışması.

Tutum" faktörü arasındaki korelasyon katsayısının .73, "Derse İlişkin Tutum” faktörü ve "Güdülenme" faktörü arasındaki korelasyon katsayısının .80 olduğu görülmektedir.

\section{Ölçeğin Güvenirliğine İlişkin Bulgular}

Taslak ölçeğin güvenirliğini hesaplamak üzere toplanan veriler üzerinde iç tutarlılık ve kararlılık analizleri yapılmıştır.

\section{İç Tutarlılık Katsayıları}

Ölçeğin faktörlere göre ve bütün olarak güvenirliğini belirlemek üzere Cronbach's Alpha güvenirlik katsayıları belirlenmiştir. Ölçeğin faktörlerine ve bütününe ilişkin ulaşılan değerler Tablo 4'de görülmektedir.

Tablo 4. Siber aylaklık Nedenleri Ölçeğinin İç Tutarlılık Düzeyleri

\begin{tabular}{lcc}
\hline Faktörler & Madde Sayısı & Cronbach's Alpha \\
\hline Güdülenme & 4 & .75 \\
\hline Yürütücü Kaynaklı Nedenler & 3 & .64 \\
\hline Derse İlişkin Tutum & 4 & .69 \\
\hline Toplam & 11 & .83 \\
\hline
\end{tabular}

Tablo 4'de görüldüğü üzere; ölçeğin "Güdülenme" faktörünün Cronbach's Alpha güvenirlik katsayısı .75, "Yürütücü Kaynaklı Nedenler" faktörünün Cronbach's Alpha güvenirlik katsayısı .64, "Derse İlişkin Tutum" faktörünün Cronbach's Alpha güvenirlik katsayıs1 .69 ve ölçeğin bütününün Cronbach's Alpha güvenirlik katsayısı ise .83'tür. Buna bulgulara göre ölçeğin faktörlerinin iç tutarlılık katsayılarının yeterli düzeyde olduğu ve bütününün iç tutarlılık katsayısının yüksek olmasına bağlı olarak, ölçeğin tutarlı ölçümler yapabildiği yorumunda bulunulabilir.

\section{Kararlılık Düzeyi}

Ölçeğin kararlılık düzeyini belirlemek için test-tekrar test yöntemi kullanılmıştır.24 erkek 20 kadın toplam 44 öğrenciden oluşan bir grupla ölçeğin puan değişmezliğine ilişkin test-tekrar test korelasyon katsayısı belirlenmiştir. Ölçek iki hafta ara ile aynı gruba uygulanmış, elde edilen veriler üzerinde Pearson korelasyon testi yapılmıştır. Bu iki uygulamada ortaya çıkan puanlar arasındaki Pearson korelasyon katsayıları Tablo 5 'te yer almaktadır.

Tablo5. Siberaylaklık Nedenleri Ölçeği’ninTest-Tekrar Test Korelasyon Katsayıları

\begin{tabular}{|c|c|c|}
\hline Faktör & $\mathbf{r}$ & $\mathbf{p}$ \\
\hline Güdülenme & .87 & .00 \\
\hline Yürütücü Kaynaklı Nedenler & .77 & .00 \\
\hline Derse İlişkin Tutum & .84 & .00 \\
\hline & .84 & .00 \\
\hline
\end{tabular}

"Güdülenme" faktörünün korelasyon katsayısı .87, "Yürütücü Kaynaklı Nedenler" faktörünün korelasyon katsayıs1 .77 ve "Derse İlişkin Tutum" faktörünün korelasyon katsayıs1 .84 olarak hesaplanmıştır. Bu değerlere göre ölçeğin kararlı ve güvenilir ölçümler yapabileceği yorumunda bulunulabilir (Büyüköztürk, 2007).

\section{SONUÇ VE TARTIŞMA}

$\mathrm{Bu}$ araştırma ile öğrencilerin bilgisayar laboratuvarında işlenen derslerde gerçekleştirdikleri siberaylaklık davranışlarını ölçmek üzere bir ölçme aracı geliştirilmiştir.Madde havuzunda toplanan 16 madde ön çalışma sonunda 14 maddeye düşürülmüş, uygulama aşamasından elde edilen verilerin analiz edilmesiyle faktör yükleri .30'un altında olan maddeler ölçekten çıkarılmış, 11 maddelik bir ölçeğe ulaşılmıştır. Alanyazın taraması, uzmanların görüşleri ve araştırmacıların gözlemlerinden hareketle oluşturulan, geçerlik ve güvenirlik çalışmaları yapılan Siber aylaklık Nedenleri Ölçeği'nin"Güdülenme", "Yürütücü Kaynaklı Nedenler" ve "Derse İlişkin Tutum" olmak üzere toplam üç alt faktörden oluştuğu ortaya koyulmuştur. Bu üç faktördeki maddelerin 


\section{F.Ü. Sosyal Bilimler Dergisi 2017-27/1}

madde faktör yükleri ve açıklanan varyans oranlarına göre ölçeğin yapı geçerliğine sahip olduğu söylenebilir.

Ölçekte yer alan maddeler "(1) Hiçbir zaman”, “(2) Nadiren”, (3) Ara sıra", "(4) Genellikle" ve "(5) Her zaman" şeklinde derecelendirilmiştir. "Güdülenme" ve "Derse İlişkin Tutum" faktörlerinden alınabilecek en düşük puan 4, en yüksek puan 20, "Yürütücü Kaynakl1 Nedenler" faktöründe ise en düşük puan 3 ve en yüksek puan 15'tir.Ölçeğin faktörleri için alınacak toplam puanlar ile öğrencilerin gerçekleştirdiği siber aylaklık davranışlarının nedenleri konusunda fikir edinilebilir.

Güdülenme öğrencilerin öğrenmeye ve ders etkinliklerine yönelmelerine ilişkin olarak iç (motivasyon) veya dış etkenleri ifade etmektedir. Derse İlişkin Tutum öğrencilerin dersi takip etme ve ders içinde kendilerine verilen görevleri yapma konusundaki tutumlarını ifade etmektedir. Yürütücü Kaynakl Nedenler ise öğrencilerin bilgisayar laboratuvarında işlenen derslerde ders yürütücüsü kaynaklı olarak (dersteki tutumu, kullandığı yöntemler vb.) siberaylaklık davranışlarına yönelmelerini ifade etmektedir.

Alanyazında güdülenme ve motivasyonun eğitim öğretim ortamlarında gerçekleştirilen siber aylaklık davranışlarına etkisi olduğunun belirtildiği çalışmalar bulunmaktadır (Ergün \& Altun, 2012; Kalayc1, 2010). Aynı şekilde öğrencilerin siber aylaklık davranışlarında derse ve ders yürütücüsüne yönelik tutumlarının etkisi olduğu görülmektedir (Ergün \& Altun, 2012; Tozkoparan, 2016). Ergün ve Altun (2012)'un çalışmasında siberaylaklık davranışlarının nedenleri "motivasyon", "ortam”, “öğretmen”, "zaman” ve "derse hedeflenme” olmak üzere 5 başlık altında toplanmıştır. Bu çalışmada siberaylaklık davranışlarıyla ilgili olarak ortaya konan nedenler de alanyazında bulunan çalışmalarla paralellik göstermektedir. Dolayısıyla bu çalışmada geliştirilen ölçme aracı ile öğrencilerin siber aylaklık davranışlarının söz konusu nedenlerinin değerlendirilebileceği yorumunda bulunulabilir. Ayrıca siberaylaklık davranışları konusunda Türkçe alanyazındaki çalışmaların sınırlılığı düşünüldügünde, bu çalışma ve çalışmada geliştirilen ölçme aracı alanyazındaki boşluğu doldurmaya katkıda bulunabilir.

Sonuç olarak; Siberaylaklık Nedenleri Ölçeği üç faktör altında toplanan, 11 maddeden oluşan 5'li likert tipi bir ölçektir. Analizler ölçeğin, bireylerin siber aylaklık davranışlarının nedenlerini ölçmeye dönük geçerli ve güvenilir bir araç olduğunu ortaya koymuştur. Çalışma sonunda elde edilen bu sonuçlara göre, Siberaylaklık Nedenleri Ölçeği’nin bilgisayar laboratuvarlarında öğrencilerin siber aylaklık davranışlarını ve nedenlerini belirlemede, eğitim kurumlarında bir ölçme aracı olarak kullanılabileceği söylenebilir.

\section{KAYNAKÇA}

Baturay, M. H.,\& Toker, S. (2015). An investigation of theimpact of demographics on cyberloafing from an educational settingangle. Computers in Human Behavior, 50, 358-366.

Bayram, N. (2010). Yapısal Eşitlik Modellemesine Giriş AMOS Uygulamaları. Bursa: Ezgi Kitabevi.

Büyüköztürk, Ş. (2007). Sosyal Bilimler İçin Veri Analizi El Kitabi. Ankara: Pegem Yayıncılık.

Çepni, S. (2010). Araştırma ve Proje Çalışmalarına Giriş. Trabzon: Celepler Matbaacılık.

Çınar, O., \& Karcioğlu, F. (2015). The Relationship between Cyberloafing and Organizational Citizenship Behavior: A Survey Study in Erzurum/Turkey. Procedia-Social and Behavioral Sciences, 207, 444-453.

Ergün, E., \&Altun, A. (2012). Öğrenci Gözüyle Siber Aylaklık ve Nedenleri. Eğitim Teknolojisi Kuram ve Uygulama, 2(1), 36-53.

Field, A. (2013). Discovering statistics using IBM SPSS statistics (4th Edition). London: Sage Publications Ltd.

Henle, C. A., Kohut, G., \& Booth, R. (2009). Designing electronic use policies to enhance employee perceptions of fairness and to reduce cyberloafing: An empirical test of justice theory. Computers in Human Behavior, 25(4), 902-910. 
Jia, H. H. (2008). Relationships between the big five personality dimensions and cyberloafing behavior. Unpublished Doctoral Dissertation. Southern Illinois University, Carbondale, IL.

Kalaycı, E. (2010). Üniversite Öğrencilerinin Siberaylaklık Davranışları İle Öz-Düzenleme Stratejileri Arasındaki İlişkinin İncelenmesi. Yayınlanmış Yüksek Lisans Tezi. Hacettepe Üniversitesi, Fen Bilimleri Enstitüsü, Bilgisayar ve Öğretim Teknolojileri Eğitimi Anabilim Dalı, Ankara.

Kara, A. (2010). Öğrenmeye İlişkin Tutum Ölçeğinin Geliştirilmesi. Electronic Journal of Social Sciences, 9(32), 49-62.

Karasar, N. (2008). Bilimsel Araştırma Yöntemi. Ankara: Nobel Yayın Dağııım.

Keser, H., Kavuk, M., \& Numanoglu, G. (2016). The relationship between Cyber-Loafing and internet addiction. Cypriot Journal of Educational Sciences, 11(1), 37-42.

Kurt, M. (2011) "Siber Aylaklık Davranışlarının Karşılaştırmalı Olarak İncelenmesi” Fırat University 5th International Computer \& Instructional Technologies Symposium, September 22-24, Elazığ.

Lim, V. K. G. (2002). The IT way of loafing on the job: cyberloafing, neutralizing and organizational justice. Journal of Organizational Behavior, 23(5), 675-694.

Lim, V. K. G. (2005). The moderating effect of neutralization technique on organizational justice and cyberloafing. Pacis 2005 Proceedings, 206-219.

Lim, V. K. G., \& Teo, T. S. H. (2006). Cyberloafing and organizational justice. In M.Anandarajan, T. S. H. Teo \& C. A. Simmers (Eds.), The Internet and Workplace Transformation (pp. 241-258). Armonk, NY: M.E. Sharpe.

Meydan, C. H., \& Şeşen, H. (2011). Yapısal Eşitlik Modellemesi AMOS Uygulamaları. Ankara: Detay Yayıncilik.

Örücü, E.,\&Yildiz, H. (2014). İşyerinde Kisisel Internet ve Teknoloji Kullanımı: Sanal Kaytarma/ThePersonal Internet and Technology Usage at the Workplace: Cyberslacking. Ege Akademik Bakis, 14(1), 99-114.

Özkalp, E., Aydın, U., \& Tekeli, S. (2012). Sapkın Örgütsel Davranışlar ve Çalışma Yaşamında Yeni Bir Olgu: Sanal Kaytarma (Cyberloafing) ve İş İlişsilerine Etkileri. Çimento Isşveren Sendikası Dergisi, 26(2), 18-33.

Pychyl, T. A. (2001). Cyberslacking and the Procrastination Superhighway. Social Science Computer Review, 19(4), 431-444.

Tozkoparan, S. B. (2016). İnternet Bağımlılı̆̆ı ve Öğrenmeye İlişkin Tutumun Siberaylaklık Davranışlarına Etkisi. Yayınlanmamış Yüksek Lisans Tezi. Mevlana Üniversitesi, Fen Bilimleri Enstitüsü, Bilgisayar ve Öğretim Teknolojileri Eğitimi Anabilim Dalı. Konya.

Tuncer, M., \& Yilmaz, Ö. (2013). Development of the Scale of Project Based Virtual Learning Qualifications. Elementary Education Online, 12(1), 109-119.

Ugrin, J. C., Pearson, J. M., \& Odom, M. D. (2011). Cyber-slacking: self-control, prior behavior and the impact of deterrence measures. Review of Business Information Systems (RBIS), 12(1), 75-88.

Ünal, Ö. F., \& Tekdemir, S. (2015). Sanal Kaytarma: Bir Kamu Kurumunda Ampirik Bir Araştırma. Süleyman Demirel Üniversitesi İktisadi ve İdari Bilimler Fakültesi Dergisi, 20(2). 95-118.

Yaşar, S. (2013). Üniversite Öğrencilerinin Denetim Odağı ve Bilgisayar Laboratuvarına Yönelik Tutumlarının Siberaylaklık Davranışlarına Etkisi. Yayınlanmış Yüksek Lisans Tezi. Hacettepe Üniversitesi, Fen Bilimleri Enstitüsü, Bilgisayar ve Öğretim Teknolojileri Eğitimi Anabilim Dalı. Ankara.

Yaşar, S., \& Yurdugül, H. (2013). The Investigation of Relation Between Cyberloafing Activities and Cyberloafing Behaviors in Higher Education. Procedia-Socialand Behavioral Sciences, 83, 600-604.

Yılmaz, F. G. K., Yılmaz, R., Öztürk, H. T., Sezer, B., \& Karademir, T. (2015). Cyberloafing as a barrier to the successful integration of information and communication technologies into teaching and learning environments. Computers in Human Behavior, 45, 290-298. 
